\title{
Global Food Security, Economic and Health Risk Assessment of the COVID-19 Epidemic
}

\author{
Sándor Kovács $1, * \mathbb{C}$, Mohammad Fazle Rabbi ${ }^{2}$ and Domicián Máté ${ }^{3,4} \mathbb{C}^{\mathbb{C}}$ \\ 1 Faculty of Economics and Business Management, University of Debrecen, H-4032 Debrecen, Hungary \\ 2 Ihrig Károly Doctoral School, University of Debrecen, H-4032 Debrecen, Hungary; drrabbikhan@gmail.com \\ 3 Faculty of Engineering, University of Debrecen, H-4032 Debrecen, Hungary; mate.domician@eng.unideb.hu \\ 4 College of Business and Economics, University of Johannesburg, Johannesburg 2006, South Africa \\ * Correspondence: kovacs.sandor@econ.unideb.hu
}

check for updates

Citation: Kovács, S.; Rabbi, M.F.; Máté, D. Global Food Security, Economic and Health Risk Assessment of the COVID-19 Epidemic. Mathematics 2021, 9, 2398. https://doi.org/10.3390/math 9192398

Academic Editor: David Carfi

Received: 1 September 2021

Accepted: 24 September 2021

Published: 27 September 2021

Publisher's Note: MDPI stays neutral with regard to jurisdictional claims in published maps and institutional affiliations.

Copyright: (c) 2021 by the authors. Licensee MDPI, Basel, Switzerland. This article is an open access article distributed under the terms and conditions of the Creative Commons Attribution (CC BY) license (https:/ / creativecommons.org/licenses/by/ $4.0 /)$.

\begin{abstract}
This study addresses the complexity of global pandemic (COVID) exposures and explores how sustainable development relates to economic and health risks and food security. Multiple factor analysis (MFA) is applied to compute the links among blocks of variables, and results are validated by random sampling with bootstrapping, exhaustive and split-half techniques, and analysis of variance (ANOVA) to test the differences of the MFA factors within the different stages of competitiveness. Comparing the MFA factors suggests that higher competitiveness is correlated with better food security and natural resilience and the tremendous economic downturn; the most competitive countries have lower exposures to health risks. In addition, the risk of pandemics appears to be lower with well-established public health care (HC) system services and good health for the population. The study also underlines that the economic and health systems are unfortunately inadequate to deal with a crisis of this magnitude. Although the countries least affected by the epidemic are the most competitive, they cannot protect people and the economy effectively. Formulating appropriate global responses is a challenge, but the results may lead to more nuanced findings regarding treatment policies that can be addressed at the country level.
\end{abstract}

Keywords: competitiveness; economic risk; food security; health risk; MFA method; risk assessment; sustainable development

\section{Introduction}

The latest SARS influenza pandemic in Wuhan, China, which became known in December 2019, broke out of Pandora's box. Since then, COVID-19 has continued to spread around the world. Due to the infectivity of the disease, global transport has been limited and even restricted across countries and quarantines. Global trade difficulties caused significant distribution issues, and the loss of agricultural labour prevented continuous production resulted in food supply disruptions. Most importantly, some sort of panic began to emerge in input-oriented and consumer-dependent companies, leading to more expensive food prices [1]. The food supply has declined due to increased uncertainty and market anomalies. In addition to the social and economic downturn, the epidemic has another necessary consequence. Global financial markets also responded to the changes, and stock indices began to decline, anticipating a protracted crisis [2].

In addition to endangering human health, the epidemic also threatened employment, food security and sustainable economic development. The pandemic recovery represents another grand challenge and an excellent opportunity to achieve the 2030 Agenda and the Sustainable Development Goals (SDGs) [3]. SDGs are pathways that can encompass almost every aspect of the well-being of humanity and would provide both prosperous lives for all people and ensure the health of the planet [4]. SDGs are required efforts to promote policies and approaches, such as SDG2 relates to "end (zero) hunger, achieve food security and improved nutrition, and promote sustainable agriculture". Food security 
"... is the state in which people at all times have physical, social, and economic access to sufficient and nutritious food that meets their dietary needs for a healthy and active life [5]". SDG8 denotes "decent work and economic growth" that improve living standards and support the elderly population with policies related to pension, social assistance and life-long education. SDG3, "ensure healthy lives and promote well-being for all at all age", aims to support the health care (HC) systems to treat chronic and infectious diseases through prevention, vaccination and rehabilitation.

The main goal of this study is to gain novel insights into whether and how SDGs can be implemented by exploring the interrelationships between the different dimensions of economic and epidemiological risks and development stages. The novelty of this exploratory approach is that global risk assessment is treated mathematically as a multidimensional construct, which may lead to more nuanced findings on how economic and health treatment policies could be addressed at the country level.

This study assumes a correspondence between the vulnerability of COVID-19 and the development stages of countries. A cross-country comparative framework is used to test this assumption, and datasets were published by SolAbility Sustainable Intelligence, European Intelligence Unit, and OurWorldinData for 2019-2021. Section 2 contains the design of selected variables and methodology. A multiple factor analysis (MFA) is applied to compute the links among blocks of variables. The advantage of MFA is calculating correlations between the indices in each dimension concerning the competitiveness stages. Sections 3 and 4 presents the results and discussion based on the developed hypothesis, and the paper ends with conclusions stemming from the results that the economic and health systems are unfortunately inadequate to deal with a crisis of this magnitude.

\section{Literature Review}

Responses to SDGs and SARS as a double helix pose a severe threat to human health and the economic environment and cannot be treated with different approaches in the future [6]. The evolution of the disease and its economic and social impacts are highly uncertain, making it difficult to understand the costs and risks of contagion in formulating appropriate responses. There are several direct and indirect channels through which outbreaks of infectious (HIV / AIDS, SARS) diseases affect the development of economies [7]. Individual perceptions of the risks associated with SARS may also be high, especially in the early stages of an epidemic when no vaccine and antiviral drugs are lacking [8]. The economic risk of an epidemic is quite different from the risk of morbidity and mortality. Besides, economic risk is determined by biohazard and exposure, resilience, and vulnerability, which has different spatial variability [9]. The population and economic activities are exposed to the pathogen or indirectly for epidemic-changing behaviour [10]. The vulnerability suggests that SARS may unfavourably affect the exposed economy. The concept of disease vulnerability was introduced as the impact of natural disasters on the population, as a kind of test of how societies can make a vulnerable population resilient when such a disaster covers the entire economy [11]. The traditional approach uses information on deaths (mortality) and condition of illnesses (cases) that prevent work [12]. However, it applies to the pathology of individual health capacity and autonomy within communities and cultures, especially social groups [13]. The speed of the process determines the degree of resilience and when the economic system returns to full recovery [14].

Several previous relevant studies have attempted to evaluate the global and economic impacts of SARS [15-17], but have only recently focused on identifying socioeconomic drivers or environmental inhibitors of SARS-CoV-2 (COVID-19) transmission [18,19]. Since then, academics have been analysing country-specific studies [20-22] due to the relatively small number of global cases. Although SARS was highly contagious, global economic and social costs were substantial and not limited only to the affected countries. To the best of our knowledge, the complexity of global pandemic exposure has been underestimated in how economic development and competitiveness relates to COVID-19-vulnerability, taking into account the economic and health risks, food safety and natural resilience. 


\section{Materials and Methods}

\subsection{Design of Variables}

This paper carefully and systematically selected variables related to economic and health care risk exposure, food security, and COVID-vulnerability. Table 1 presents the variables and their descriptions. The data were collected in United Nations (UN) countries (112) between 2019 and 2021. During the COVID crisis the population deaths and infections were used from the first known (2019) cases until 2021. The global food security, economic and health risks were related to the year (2019) before the onset of the crisis.

Table 1. Description of indicators.

\begin{tabular}{|c|c|c|c|c|}
\hline Pillar & Variables & Description & Measurement & Source \\
\hline \multirow{5}{*}{ Economic Risk } & $\begin{array}{l}\text { Economic } \\
\text { Independence }\end{array}$ & $\begin{array}{c}\text { Dependency on imports/exports, } \\
\text { employment in service and agricultural } \\
\text { sectors, as well as innovation capabilities }\end{array}$ & (1-5) 1-least & \multirow{5}{*}{ [23] } \\
\hline & Fall from the Cliff & $\begin{array}{l}\text { A potential } 10 \% \text { reduction in GDP is } \\
\text { significantly higher in absolute terms in } \\
\text { high-income countries. }\end{array}$ & (1-5) 1-least & \\
\hline & Equality Resilience & $\begin{array}{c}\text { Internal inequality measurements (income } \\
\text { and asset share hold by the lowest 20\%, } 40 \% \\
\text { and } 60 \% \text { ) }\end{array}$ & (1-5) 1-least & \\
\hline & $\begin{array}{c}\text { Status of } \\
\text { Government Finance }\end{array}$ & $\begin{array}{l}\text { The current state of government debt and } \\
\text { interest payments }\end{array}$ & (1-5) 1-least & \\
\hline & $\begin{array}{c}\text { Financial Markets } \\
\text { Volatility }\end{array}$ & $\begin{array}{l}\text { Private and corporate debt, as dependency on } \\
\text { stock markets (measured as the value of stock } \\
\text { and annual stock turnover) }\end{array}$ & (1-5) 1-least & \\
\hline \multirow{4}{*}{ Health Risk } & $\begin{array}{l}\text { HC (Health Care) } \\
\text { Infrastructure }\end{array}$ & $\begin{array}{l}\text { Availability of HC infrastructure (number of } \\
\text { beds, doctors and nurses per capita; mortality } \\
\text { rate from non-communicable diseases) }\end{array}$ & (1-5) 5-worst & \multirow{4}{*}{ [23] } \\
\hline & HC System & $\begin{array}{l}\text { HC spending per capita, out-of-pocket } \\
\text { affordability for the lower-income segment, } \\
\text { government share on spending, the mortality } \\
\text { rate of lifestyle diseases }\end{array}$ & (1-5) 5-worst & \\
\hline & Risk Group Size & $\begin{array}{c}\text { Elderly population measured by the } \\
\text { percentage of the population over age } 65,50, \\
\text { and } 40\end{array}$ & (1-5) 5-eldest & \\
\hline & $\begin{array}{c}\text { General Population } \\
\text { Health }\end{array}$ & $\begin{array}{l}\text { Life expectancy, mortality rates due to air } \\
\text { pollution, and general fitness level measured } \\
\text { through average standardised } \\
\text { body-mass-index }\end{array}$ & (1-5) 5-worst & \\
\hline \multirow{4}{*}{$\begin{array}{c}\text { Global } \\
\text { Food Security }\end{array}$} & Affordability & $\begin{array}{l}\text { The ability of consumers to purchase food, } \\
\text { their vulnerability to price shocks and the } \\
\text { presence of policies to support them }\end{array}$ & $\begin{array}{l}\text { Score }(0-100) \\
100=\text { best }\end{array}$ & \multirow{4}{*}{ [24] } \\
\hline & Availability & $\begin{array}{l}\text { The availability ensures sufficient food supply, } \\
\text { low risk of supply disruption, and high } \\
\text { national capacity to disseminate food and } \\
\text { research efforts to expand agricultural output. }\end{array}$ & $\begin{array}{l}\text { Score }(0-100) \\
100=\text { best }\end{array}$ & \\
\hline & Quality and Safety & $\begin{array}{l}\text { Variety and nutritional quality of average } \\
\text { diets and the safety of food }\end{array}$ & $\begin{array}{l}\text { Score }(0-100) \\
100=\text { best }\end{array}$ & \\
\hline & $\begin{array}{l}\text { Natural Resources } \\
\text { and resilience }\end{array}$ & $\begin{array}{l}\text { Exposure to the impacts of climate change; its } \\
\text { susceptibility to natural resource risks; and } \\
\text { how the country is adapting to these risks }\end{array}$ & $\begin{array}{l}\text { Score }(0-100) \\
100=\text { best }\end{array}$ & \\
\hline \multirow{2}{*}{$\begin{array}{c}\text { COVID } \\
\text { Vulnerability }\end{array}$} & Deaths & $\begin{array}{l}\text { Total number of deaths per } 1 \text { million residents } \\
\text { from the first case (2019) till 18/04/2021 }\end{array}$ & capita/thousand & \multirow[b]{2}{*}{ [25] } \\
\hline & Cases & $\begin{array}{l}\text { Total number of infections per } 1 \text { million } \\
\text { residents from the first case (2019) till } \\
18 / 04 / 2021\end{array}$ & $\begin{array}{l}\text { number of } \\
\text { cases/million }\end{array}$ & \\
\hline
\end{tabular}


The economic and health risk pillars contain various World Health Organization (WHO) and World Bank (WB) indices collected by the SolAbility Sustainable Intelligence [23]. Quantitative, measurable data sets on straightforward health care and economic performance highlight the potential impacts of the COVID-19 epidemic on altered countries in terms of global downturn and competitiveness. The perception of global sustainable competitiveness is based on the conviction that economic and human development and ecological sustainability are essential elements for high productivity and a welfare society [26].

The initial pillar exposed to health risks is general health, demographics, and access to health infrastructure and funding indicators. Health risks are shaped by the response issues and capabilities of each country. The general health and mortality of the average persons, the size of the risk groups (elderly), the availability of health infrastructure (hospital beds, doctors, nurses), and the health sector's financial situation reflect the appropriate risks before the pandemic.

The risks of the economic slump pillar involve the five key areas that determine the economy's resilience, i.e., the independence of global markets, the state of public finances, exposure to financial market fluctuations, internal income inequality, and the 'height' of the economic fall. The economic decline depends upon crisis management and the response to pandemic crises.

Global food security indicators were provided by the European Intelligence Unit [24]. The pillar considers food affordability, availability, quality and safety, and natural resources and resilience, all of which affect the incidence of food insecurity across countries. Affordability measures the capacity and cost of food payments and vulnerability to dependence control against external price shocks. Accessibility refers to the risk of food supply to expand agricultural production and reduce food waste and loss, and political instability. The food quality and safety index measures sound quality and varied nutrition. The natural resources and resilience assess exposure to the effects of a changing climate and its sensitivity to the risks of natural resources (i.e., climate disasters, water scarcity and land quality issues, and population pressures).

Data on COVID-19 pandemic indicators (deaths and infections) were obtained from the updated OurWorldinData research and statistics [25]. Classification by economic development based on the stages set out in the World Economic Forum (WEF) Global Competitiveness Report [27]. In line with the economic theory of Porter's stages of development, in the first stage (Stage 1), factor-driven countries compete based on their endowments, primarily (unskilled) labour and natural resources [28]. As the economy becomes competitive, productivity growth and wages increase. Countries then enter the efficiency-driven development phase (Stage 3). Lastly, when countries enter the innovation-driven phase (Stage 5), wages will rise so high that they will only be sustainable if companies use the most advanced production processes. Transitions between each stage are captured by Stages 2 and 4 (from 1 to 3 and 3 to 5).

\subsection{Multiple Factor Analysis (MFA)}

The MFA method was first introduced by Thurstone [29] and later described by Escoffier and Pagès [30]. MFA has recently been used in various scientific fields, such as agriculture [31,32]; business management and economics [33,34]; chemometrics [35,36]; health and medicine [37]; mathematics and statistics [38,39]. The method is advantageous in analysing a given table of inter-correlated variables that are in multiple blocks.

Denote by $X_{o x v}=\left(x_{i j}\right)$ the raw dataset (table) that contains observations $(o)$ in the rows and variables (v) across the columns. $x_{i j}$ is the entry in the $i$-th row, and $j$-th column of the table, where $1 \leq i \leq 0 ; 1 \leq j \leq v$ and $o$ is the number of objects, $v$ is the number of variables. Each observation is weighted by importance called mass. All masses are equal to $1 / o$, and the mass matrix is diagonal and denoted by $M$. The raw dataset of the same observations consists of $K$ variable blocks (which are sub-tables), and $X_{[k]}$ denotes the $k$-th 
block (sub-table), where $1 \leq k \leq K$. The original data table can be divided into $K$ sub-tables according to:

$$
X=\left[X_{[1]}, \ldots, X_{[k]}, \ldots, X_{[K]}\right]
$$

Each block should be made comparable by setting the average of each column to 0 and the sum of the squared values to 1 . Denote the preprocessed data matrix by $\widetilde{X}$ and the $k$-th block in it by $\widetilde{X}_{[k]}$. The analysis aims to represent $\widetilde{X}$ with a linear combination of new components, which explains the maximum variance by considering the common structure of the blocks.

The MFA analysis consists of three stages: (1) singular value decomposition (SVD) of each block; (2) the first singular value of each block is used to normalise the blocks; (3) and generalised SVD of the total preprocessed data $(\widetilde{X})$ is performed. In the first stage, SVD is performed according to the following:

$$
\widetilde{X}_{[k]}=S_{[k]} V_{[k]}^{T} D_{[k]},
$$

where $D_{[k]}$ is a diagonal matrix containing the singular values (which can be treated as standard deviations) in the main diagonal. $S_{[k]}$ and $V_{[k]}$ satisfies the following equation ( $U$ stands for the unit matrix, $T$ denotes the transposition):

$$
U=S_{[k]}^{T} S_{[k]}=V_{[k]}^{T} V_{[k]}
$$

The first singular value is denoted in $D$ by $d_{11}$, and $w_{1}=\frac{1}{d_{11}^{2}}$ is the weight for the first block. For the $k$-th block $\left(w_{k}=\frac{1}{d_{k k}^{2}}\right)$, where $d_{k k}$ is the $k$-th singular value in $D$. Let $W$ be a diagonal weight matrix containing the $w_{1}, \ldots, w_{k}, \ldots, w_{K}$ weights. The rule is that all the variables in the same block have the same weight.

Finally, the generalised SVD of all preprocessed data is performed on $\widetilde{X}$ :

$$
\widetilde{X}=P L Q^{T}=F Q^{T} \text {, with } P^{T} M P=Q^{T} W Q=U,
$$

where $L$ is a diagonal matrix containing the singular values, and $F=P L$ is the so-called factor scores matrix that describes the observations, $Q$ is the so-called loading matrix of the variables. The columns of the $F$ matrix (usually the first two) are the MFA factors (also known as dimensions) used to represent the observations, and the $Q$ columns contain the variables. $F$ can be obtained from Equation (4), such as follows:

$$
F=\widetilde{X} W Q
$$

Due to the entire block structure, MFA provides a unique concept of partial factor scores that allows each observation to be positioned for different groups of variables [40]:

$$
F=\sum_{k} F_{[k]}=\frac{1}{K} \sum_{k} K \cdot \widetilde{X}_{[k]} \cdot w_{[k]} \cdot Q_{[k]}
$$

where $F_{[k]}$ is the partial factor score of the $k$-th block.

MFA is preferred for the graphical display of observations and construction of diverse clusters [35]. The analysis results also represent the relationships between the objects (factor scores) and the groups of variables examined. This mode of representation is called the correlation circle (See Figure 1), which depicts the relationship between raw variables and factor scores in a unit circle [40]. MFA is advantageous for analysing observations defined by diverse groups of variables, and the method will be even more valuable when the dataset is large and more complex [41]. Formal analysis was performed by FactoMiner, an $R$ software package for multivariate analysis [42]. 


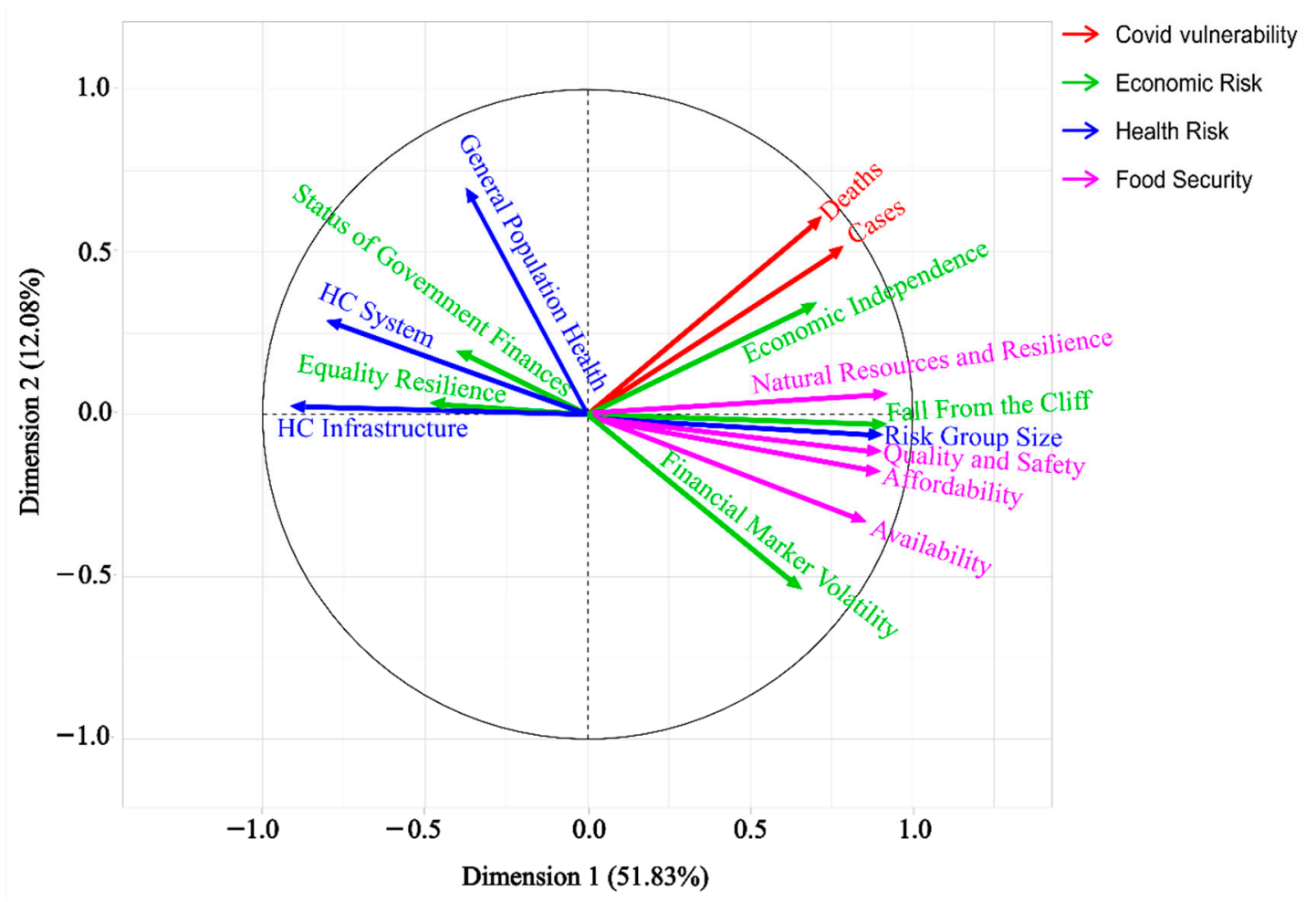

Figure 1. Correlation plot of individual blocks (food security, risk exposures and COVID-vulnerability) and the correlations of each indicator to the first two dimensions. DIM1 corresponds to 51.83\%, DIM2 explains $12.08 \%$ of inertia.

\section{Results}

The correlation circle plot discloses the common structure of the four examined pillars (groups of variables) in the MFA model. Figure 1 shows how MFA factors (dimensions) correlate with specific risk factors. The figure also suggests that the first dimension (DIM1) is well linked to global food security indices (primarily food affordability, quality and security, natural resources and resilience), economic risks (primarily due to falling from the cliff and equality resilience), and health risk factors, most notably the size of the risk group, HC infrastructure. The second dimension (DIM2) can be interpreted as COVID-vulnerability measured by the total number of deaths and infected cases during the pandemic crisis. The second dimension is also related to the health status of the general population. The eigenvalue of DIM1 corresponds to $51.83 \%$ of the inertia; DIM2 explains $12.08 \%$. MFA explained a relatively high $64 \%$ of the total variance, which is considered satisfactory.

The correlation circle is also needed when interpreting objects in the global space of MFA. The direction of the vectors is essential. For example, countries with higher DIM1 factor scores have higher food security and, therefore, a higher proportion of older people due to their development. These countries are more likely to experience a possible $10 \%$ decline in GDP during the crisis. In addition, countries with lower or negative factor scores have higher internal inequalities and exposure to HC infrastructure risk. In other words, income or wealth inequality, mortality rates are high within these nations, and the ratio of doctors and staff per bed is low. However, they are less exposed to the potentially massive decline in GDP, and the proportion of older people is low.

Moreover, it is possible to examine how each country are related to different sources of risk (economic and health exposure, global food security, COVID-vulnerability) based on their stages of development. The competitiveness related stages are only used as an additional qualitative variable in the MFA analysis, as it differs from the variable blocks (sources of risk). The partial factor score of each index is projected onto a so-called consensus map according to the supplementary variable (stage). Each stage is marked with a dot, and for each stage, a line links the factor score of the stage to the partial factor score of a particular risk type. 
Figure 2 shows each development stage as a single point on a two-dimensional map representing the overall level of competitiveness. Each level of stages increases in parallel with the first (DIM1) dimension. The partial points allow positioning nations according to different sources of risk. In this way, it can be evaluated how each source of risk affects the overall level of the competitiveness stages. The global space map can be allocated into four quarters based on the two dimensions. Each quadrant contains countries belonging to different stages and with different risk profiles.

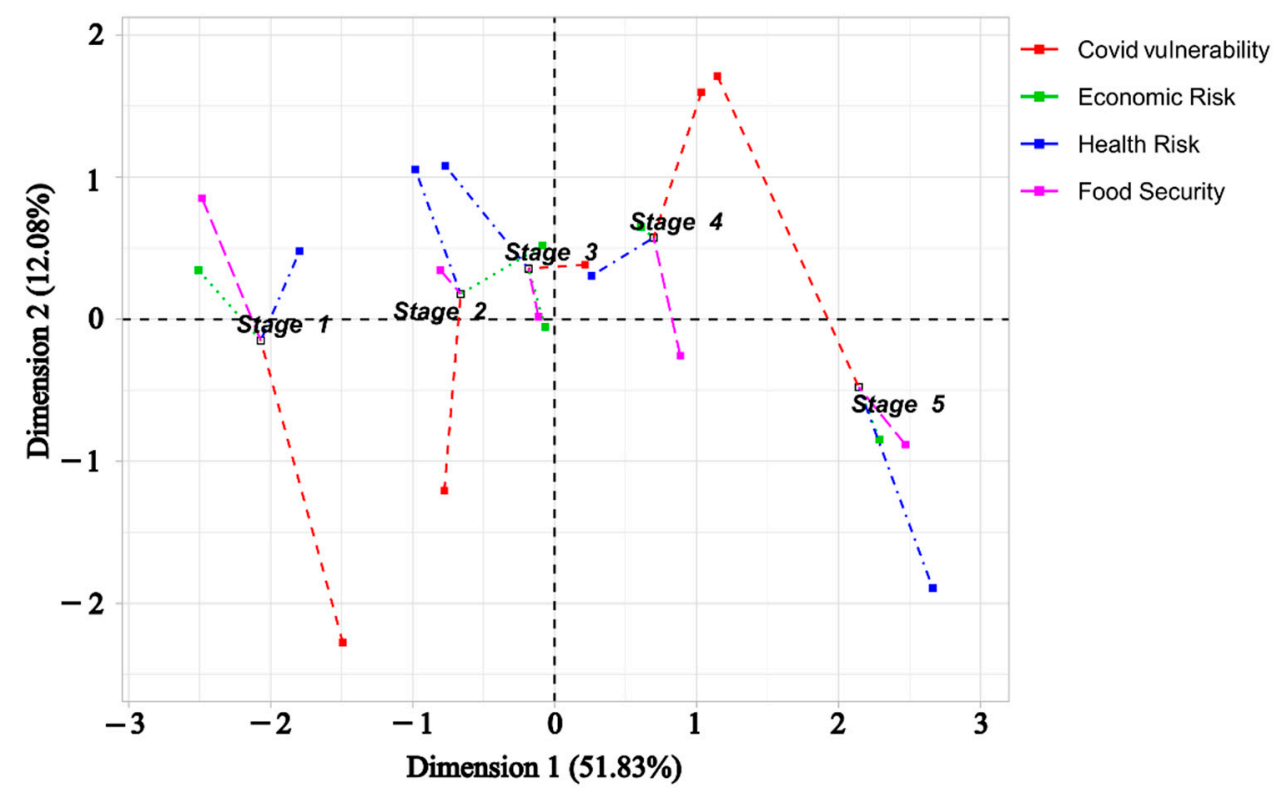

Figure 2. The contributions (partial factor scores) of each block (risk exposures) to the development stages.

The first quadrant mainly includes Stage 4 countries with relatively high vulnerabilities, the most exposed to COVID. Stages 2 and 3 efficiency-driven countries are primarily in the second quarter and face higher health risks. The difference between Stage 2 and 3 countries is that Stage 2 has a lower degree of COVID-vulnerability. Stage 1 factor-driven countries are in the third quadrant and are more exposed to food insecurity and health risks (lower life expectancy with higher mortality, the lower health status of the general population). Quadrant 4 includes Stage 5 innovation-driven countries. These countries are less exposed to health risks, and food security is not an issue here. However, there is a higher risk of COVID-vulnerability. The figure shows that most of the variance is due to pandemic vulnerability, health risk exposure, food security and resilience.

Figure 3 shows the two-factor indicators of each country. The first one (dimension) is related to competitiveness, which shows the development of the different stages. Countries are represented in different colours according to their level of development stages. The right side of the (DIM1) dimension includes developed countries with better HC systems and food security but more significant economic risks. The left side of this dimension shows less developed countries with lower levels of food security, HC infrastructure and competitiveness. The second dimension is related to exposure to health risks and COVID-vulnerability. The upper side of the (DIM2) vertical axis is linked to more COVIDvulnerable countries at high health risk. 


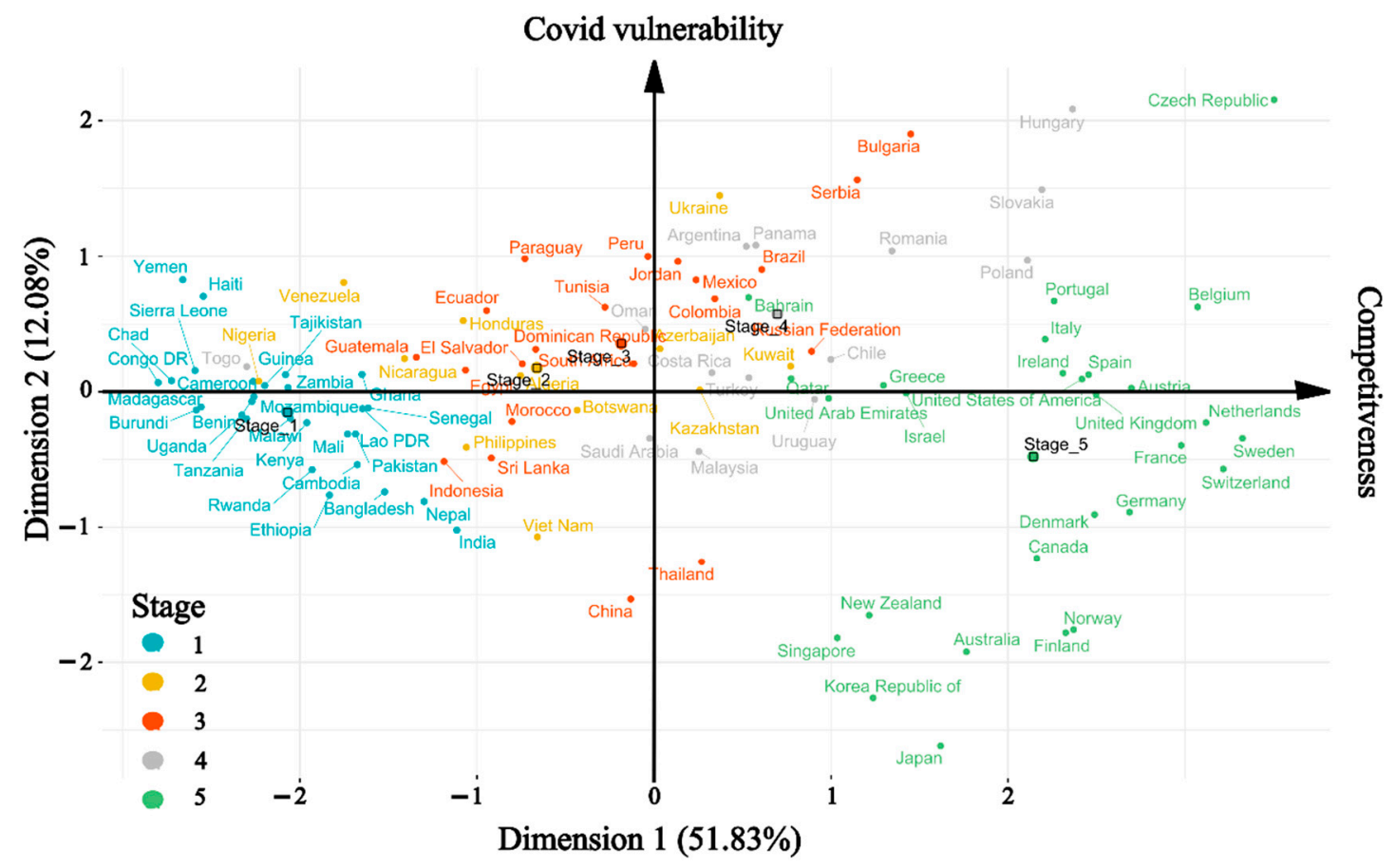

Figure 3. MFA map of different countries on COVID vulnerability and competitiveness.

The following table (Table 2) shows the rankings of the best and worst-performing countries based on MFA factors.

Table 2. MFA factors ranking by COVID-vulnerability, economic and health risk and food security.

\begin{tabular}{|c|c|c|c|c|c|c|c|c|c|}
\hline Type & Rank & Country & COVID & Country & $\begin{array}{c}\text { Economic } \\
\text { Risk }\end{array}$ & Country & $\begin{array}{l}\text { Health } \\
\text { Risk }\end{array}$ & Country & $\begin{array}{c}\text { Food } \\
\text { Security }\end{array}$ \\
\hline \multirow{10}{*}{ Best } & 1 & Bahrain & -1.66 & Tanzania & -2.99 & Japan & -2.21 & Finland & 2.84 \\
\hline & 2 & Israel & -1.28 & Uganda & -2.85 & Singapore & -2.21 & Ireland & 2.74 \\
\hline & 3 & Qatar & -1.28 & Burundi & -2.76 & South Korea & -1.99 & Sweden & 2.71 \\
\hline & 4 & Serbia & -1.14 & Chad & -2.6 & Viet Nam & -1.73 & Norway & 2.67 \\
\hline & 5 & Kuwait & -0.89 & Congo DR & -2.38 & Cambodia & -1.57 & Switzerland & 2.62 \\
\hline & 6 & $\begin{array}{c}\text { United Arab } \\
\text { Emirates }\end{array}$ & -0.86 & Madagascar & -2.35 & Bangladesh & -1.44 & Denmark & 2.57 \\
\hline & 7 & Netherlands & -0.71 & Nigeria & -2.35 & India & -1.43 & Netherlands & 2.46 \\
\hline & 8 & Turkey & -0.59 & Rwanda & -2.29 & Ethiopia & -1.21 & Canada & 2.42 \\
\hline & 9 & Jordan & -0.56 & Cameroon & -2.29 & Rwanda & -1.21 & USA & 2.42 \\
\hline & 10 & Sweden & -0.47 & Malawi & -2.29 & Nepal & -1.03 & Austria & 2.41 \\
\hline \multirow{10}{*}{ Worst } & 10 & South Africa & 0.42 & South Korea & 2.12 & Azerbaijan & 1.28 & Guinea & -2.35 \\
\hline & 9 & Brazil & 0.44 & Finland & 2.18 & Kazakhstan & 1.35 & Haiti & -2.47 \\
\hline & 8 & $\begin{array}{l}\text { United } \\
\text { Kingdom }\end{array}$ & 0.59 & Denmark & 2.19 & Slovakia & 1.35 & Venezuela & -2.74 \\
\hline & 7 & Slovakia & 0.65 & $\begin{array}{l}\text { United Arab } \\
\text { Emirates }\end{array}$ & 2.19 & South Africa & 1.36 & Burundi & -2.92 \\
\hline & 6 & Ecuador & 0.65 & Australia & 2.2 & Hungary & 1.56 & Mozambique & -2.95 \\
\hline & 5 & Italy & 0.67 & Belgium & 2.21 & Romania & 1.65 & Madagascar & -2.98 \\
\hline & 4 & Peru & 0.72 & Germany & 2.35 & Serbia & 1.88 & $\begin{array}{l}\text { Sierra } \\
\text { Leone }\end{array}$ & -3.02 \\
\hline & 3 & Hungary & 1.05 & Sweden & 2.55 & Bulgaria & 1.88 & Chad & -3.10 \\
\hline & 2 & Bulgaria & 1.10 & Netherlands & 2.66 & Ukraine & 2.27 & Congo DR & -3.64 \\
\hline & 1 & Mexico & 1.37 & Switzerland & 3.32 & $\begin{array}{l}\text { Russian } \\
\text { Federation }\end{array}$ & 2.32 & Yemen & -3.75 \\
\hline
\end{tabular}

As discussed earlier, the most COVID-vulnerable countries are South American (Ecuador, Peru) and Mexico, thus South Africa, and most Eastern-European countries (Hungary, Slovakia, and Bulgaria) with high health risks exposure have one of the worst positions. The risk appears to be lower in the countries with well-established public health 
services (Israel, Netherlands). The more economically developed OECD countries appear to be at a tremendous economic downturn due to the current global pandemic. The less developed (African) ones are exposed to below-average economic risk, but this is to some extent related to the lower level of living standard. Food security and natural resilience are fundamental aspects of sustainable development, and the analyses suggest that food security is positively related to the level of competitiveness stages. The most insecure countries are Yemen and the African ones (Sierra Leone, Chad, and Congo), and the most secure region is Scandinavia (Finland, Sweden, and Norway).

\subsection{Validation of the MFA Results}

MFA factors are validated based on several methodologies, i.e., random sampling with replacement (bootstrapping), exhaustive (leave-one-out, LOO) [43] and non-exhaustive (split-half) techniques [44] (See Table 3). These cross-validation techniques are crucial in assessing the accuracy of predictive models in practice [45].

Table 3. Validation results of the explanatory power of MFA factors.

\begin{tabular}{|c|c|c|c|c|c|c|c|}
\hline \multirow{3}{*}{ Dimension } & \multirow{3}{*}{$\begin{array}{c}\text { Explained } \\
\text { Variance }(\%)\end{array}$} & \multirow{2}{*}{\multicolumn{3}{|c|}{$\begin{array}{c}\text { Bootstrap } \\
\begin{array}{c}\text { Simulation } \\
(p \text {-Value })\end{array} \\
\text { Sample Size }\end{array}$}} & \multirow{3}{*}{$\begin{array}{c}\text { Split-Half } \\
\text { Test }^{*} \\
(p \text {-Value })\end{array}$} & \multirow{3}{*}{$\begin{array}{c}\text { LOO ** } \\
\text { Validation for } \\
\text { Observations } \\
\text { (\% of Variation) }\end{array}$} & \multirow{3}{*}{$\begin{array}{c}\text { LOO } * * \\
\text { Validation for } \\
\text { Variables } \\
\text { (\% of Variation) }\end{array}$} \\
\hline & & & & & & & \\
\hline & & $n=10$ & $n=50$ & $n=100$ & & & \\
\hline 1. & $51.8 \%$ & 0.722 & 0.916 & 0.940 & 0.841 & 3.6 & 3.5 \\
\hline 2. & $12.1 \%$ & 0.102 & 0.384 & 0.600 & 0.220 & 2.0 & 5.7 \\
\hline 3. & $9.6 \%$ & 0.614 & 0.992 & 0.952 & 0.656 & 4.6 & 6.8 \\
\hline
\end{tabular}

First, a bootstrap simulation is performed for different sample sizes $(n=10 ; 50 ; 100)$, with repetition within each indicator in each iteration $(N=1000$, where $N$ is the total number of iterations). From the distributions testing the concerns of the null hypothesis, the two-sided $p$-values concerned to the initially explained variances do not differ from those simulated. Concerning the split-half test, the dataset is halved into equal parts, and a separate MFA analysis is performed for each part.

This process is repeated $N=1000$ times, and the explained variance of the MFA factors is recorded and compared using a Wilcoxon signed-rank sample test [46]. The lack of significance indicates no statistical difference between the two splits, and the first component is the most stable for this type of study. During leave-one-out validation, MFA is performed in two ways, either by omitting observations or variables. In the first version of the test, each country is excluded from the analysis. The coefficient of variation (standard deviation divided by the mean) is estimated for each component. The coefficient of variation must not exceed the critical $20 \%$. In the second version of the test, each variable is omitted from each block once, and the variability of MFA factors is assessed as previously discussed. LOO validations show that due to missing observations or variables, the percentage of variation in the explaining performance of each component is less than $10 \%$. Based on the results, the selected first two components proved to be stable during the validation tests and explain sufficient variance with less variability if an observation or a variable is omitted from the model. The most stable component is the first, which reflects competitiveness.

\subsection{Robustness Test of Variances}

Analysis of variance (ANOVA) is used to analyse the differences of the four pillars between the stages. In order to accomplish that, the between and within stage variances are calculated. ANOVA provides statistical evidence of whether the two types of variances (between and within) are equal or not. The F-test is used (Table 4) to compare the between and within mean squares of each factor. F-test is the average of the squared differences 
between the observations and the grand mean (also called sum of squares). For all pillars, the equality of between and within stage variance was not fulfilled at $0.05 p$-level. This result means that the factors differ between the stages, and variance is much lower.

Table 4. ANOVA analysis of the selected pillars.

\begin{tabular}{|c|c|c|c|c|c|c|}
\hline Pillars & Stages & Sum of Squares & df & Mean Square & $\mathbf{F}$ & Sig. \\
\hline \multirow{4}{*}{ Economic risk } & Between & 181.149 & 4 & 45.287 & 63.298 & $<0.001$ \\
\hline & Within & 70.116 & 98 & 0.715 & & \\
\hline & Total & 251.264 & 102 & & & \\
\hline & Levene Test & & & & 0.984 & 0.420 \\
\hline \multirow{4}{*}{ Health risk } & Between & 20.224 & 4 & 5.056 & 8.513 & $<0.001$ \\
\hline & Within & 58.201 & 98 & 0.594 & & \\
\hline & Total & 78.425 & 102 & & & \\
\hline & Levene Test & & & & 1.014 & 0.404 \\
\hline \multirow{4}{*}{ Food security } & Between & 229.909 & 4 & 57.477 & 87.984 & $<0.001$ \\
\hline & Within & 64.021 & 98 & 0.653 & & \\
\hline & Total & 293.930 & 102 & & & \\
\hline & Levene Test & & & & 0.659 & 0.622 \\
\hline \multirow{4}{*}{ COVID } & Between & 2.294 & 4 & 0.573 & 3.324 & 0.013 \\
\hline & Within & 16.906 & 98 & 0.173 & & \\
\hline & Total & 19.200 & 102 & & & \\
\hline & Levene Test & & & & 6.758 & $<0.001$ \\
\hline
\end{tabular}

One major condition of the ANOVA is the homogeneity of the variance (total variance should be equal overall stages). Homogeneity test is required because the stage levels are not uniformly distributed (frequency 1: $27.2 \%$; : 11.7\%; 3: 20.4\%; 4: $13.6 \% ; 5: 27.2 \%$ ). The Levene test is applied to test the homogeneity of variance assumption. The test shows that only COVID vulnerability violates this assumption. Hence, a nonparametric Welch-test (unpaired $t$-test) has to be run for only this factor. This test proves the lack of significance $(\mathrm{F}(4,31.6)=2.404 ; p=0.070)$ at a $\%$ significance level, highlighting no significant difference between the level of competitiveness and COVID-19 deaths and infectious cases.

Finally, it can be stated that the MFA factors generated (per block) are different in each stage (Table 5). Lower values are better for economic and health risks, COVID variables and higher values are more desirable for food security.

Table 5. MFA factors per pillars and competitiveness stages.

\begin{tabular}{ccccc}
\hline Stages/Pillars & Economic Risk & Health Risk & Food Security & COVID \\
\hline 1 & -1.90 & -0.54 & -1.98 & 0.05 \\
2 & -0.02 & 0.42 & -0.64 & -0.06 \\
3 & 0.04 & 0.53 & -0.08 & 0.22 \\
4 & 0.42 & 0.42 & 0.70 & 0.04 \\
5 & 1.67 & -0.24 & 1.96 & -0.21 \\
\hline
\end{tabular}

From this point of view, it is clear that economic risks and food security and resilience are moving in parallel with competitiveness stages. In other words, the better is food security, the higher is the competitiveness, but also greater is the risk of an economic downturn. Health risk exposure is low in the most competitive (Stage 5) innovation-driven countries due to the high quality of HC systems and factor-driven (Stage 1) countries where an ageing society is still not a problem. However, there is no clear evidence of a link between COVID-vulnerability and the development stages, but it can be stated that the least pandemic affected countries are the most competitive ones. 


\section{Discussion}

An essential finding of MFA is that exposure to health risks and food insecurity is one of the lowest in the most competitive countries least affected by a pandemic. Implications are manifold.

WHO shows that two groups of people are more likely to be affected by the coronavirus: the older people without an underlying health care system and pre-existing non-communicable diseases (NCDs) [47]. Kashnitsky and Aburto [48] have shown that older people are much more at risk of death. Thus, people affected by NCDs, such as cancer, diabetes, chronic respiratory (COPD), and cardiovascular diseases (high blood pressure, stroke) are more likely to contract the virus more severely.

Not surprisingly, the highest COVID-19 deaths were reported in high-income countries (Central and Eastern Europe) where obesity, sedentary lifestyles and smoking habits were most prevalent [49]. Schoeder [50] also found more chronic conditions, which directly increased the likelihood of obesity. Meanwhile, in the case of Scandinavian and Mediterranean developed countries, where much of society follows an elderly, but a healthier lifestyle [47], such as people access to eat a diversified diet with lots of fish, fruit and vegetables, are physically active, quit smoking, limit or avoid alcohol intake, and obtain enough sleep. Similarly, the World Bank classifies high-income countries as having higher rates of COVID-19 morbidity and mortality than low-income countries due to the lack of ageing issues and the lower proportion of NCDs [51].

Health and social security should provide adequate basic care for all, regardless of income, directly and with additional health insurance. Despite many people losing their previous lives and being disrupted by the epidemic, leading governments have been reluctant to invest appropriately in their public health care systems, not to mention in less developed countries, where lots of infectious diseases are likely to originate. Economic costs could be ominously avoided with more significant investment in public health care, primarily in economies where HC systems are less developed, and population density is high [2]. Ji et al. propose to upsurge the availability and accessibility of medical resources in the $\mathrm{HC}$ for the resource-limited regions on preparing for possible local epidemics [52].

Economic vulnerability also carries a substantial risk of stress and deterioration in mental health [53]. Others have found increased depression, insomnia, and deteriorating quality of life as a characteristic effect of coronavirus on mental health in Austria [54]. In addition, physical disturbance due to an outbreak of COVID-19 have a drastically negative effect on the mental health of the elderly, including stress, anxiety and depression [51]. Most people with chronic illnesses have lost their jobs in specific sectors of the economy, such as tourism and retail [55]. The occurrence and spread of COVID-19 suggest that good governance structure, investment in HC infrastructure and learning from past epidemics have the most significant impact on the proper responses to proactive labour market strategies [56] and achieving decent work and economic growth [57].

SARS-CoV-2 can also actively infect and replicate in the gastrointestinal tract. Adopting better hygiene practices can be a cheap and highly effective response that can reduce infection and social and economic costs [58]. Adherence to this strategy can have significant consequences in treating diseases, transmission and control of infections [59]. The availability and accessibility of clean and safe water, sanitation and hygiene services (WASH) are also essential in the fight against the coronavirus and in maintaining billions' sustainable health and well-being [60]. The COVID epidemic cannot be curbed without vulnerable people having access to safe food and unpolluted water and therefore not supporting core facilities for more affected, low-capacity and fragile countries [61].

Sustainable (renewable) energy solutions must also be a priority [62], especially in sub-Saharan Africa and other desert regions, critical for health clinics and first aiders. All this is needed to reach vulnerable consumers, increase reliable, uninterrupted and sufficient energy production and health care systems to prepare for economic recovery [63]. Meanwhile, the environmental costs of materials and manufacturing must be included in 
the accurate market price for optimal water, energy and food security [64], and must be fiscally neutral about the global energy-related and carbon tax [65].

For years, scientists have warned that unrestricted deforestation [19], illegal wildlife trade, and animal-to-human disease unleashes a globally uncontrollable epidemic [66]. More explicitly, the prevalence of infectious diseases in humans is zoonotic, and these diseases are closely related to the health of ecosystems [67]. Green economies that benefit the environment or conserve natural resources are essential to restoring the balance between people and the planet and supporting economic and social recovery [68]. Green or greencollared jobs can also protect people and societies and make them more resilient to economic downturns through a fair and inclusive transition to sustainable and inclusive growth [69].

SDGs are difficult to delineate and implement simultaneously due to their complexity and interdependence. Hence, future research has to be carried out across different disciplines to retrace and develop novel and combined indicators that reflect the potential trajectories of pandemic issues. For example, researchers may consider physical and mental health behaviours as a goal, as they also reduce other risks, such as changes in decent working conditions, productive employment to promote sustainable, inclusive economic development.

\section{Conclusions}

The objective of this study was to examine the interrelations of pandemic (COVID) risk exposures to shed light on novel research perspectives on Sustainable Development Goals (SDGs). A multiple factor analysis (MFA) approach was used to calculate correlations between the risk pillars while also taking the competitiveness stages of examined countries into account. The advantage of the MFA method is that it analyses various types of observations described by groups of variables and is even more valuable when the dataset is large and complex.

Contrary to previous approaches, the complexity of pandemic risks was considered by analysing COVID-vulnerability, economic and health exposure, and global food security and resilience, which is essential for exploring the interconnections of socioeconomic and environmental issues. The MFA factors generated are different in each development stage, namely: (a) the better is food security, the higher is the competitiveness, but also greater is the risk of an economic downturn; (b) health risk exposure is low in the most competitive innovation-driven countries and the factor-driven countries.

In the ranking of MFA factors by country, (c) the most COVID-vulnerable countries are South American, Eastern-European ones, thus South Africa; (e) the pandemic health risk appears to be lower in the countries with well-established public HC services and good general health conditions, such as Israel, Netherlands. (f) Controversially to Noy and Doan [9], it can be stated that the least pandemic affected countries are the most competitive ones, and the less developed (African) ones are exposed to below-average economic risk.

Consequently, the coronavirus epidemic again shows that the global economic and health systems are unfortunately not sustainable, even inadequate to deal with a crisis of this magnitude. Although there is no clear evidence to accept the presumption of correspondence between COVID-vulnerability and economic development, the countries least affected by the epidemic are the most competitive. However, they are also unable to protect people and the economy effectively.

The present study makes vital contributions. First, the study investigated the global risks of the coronavirus epidemic associated with economic and health systems and the most prominent food security for exploring the interconnections of socioeconomic and environmental issues. Secondly, the study first used multivariate factor analysis (MFA) to link multiple risk pillars and introduces some validation techniques, which is also novel because the method works with blocks of variables.

The practical implication of the study is that policymakers need to pay attention to three areas: exposure to economic and health risks and global food security for economic and structural reforms. Green economies that benefit the environment or conserve natural 
resources to address socio-economic and environmental issues reduce the risk of economic downturn. In less developed countries, investment in health is essential to improve the ability to reduce physical and mental illness to withstand the onset of contagious diseases. Decent working conditions are needed worldwide to promote inclusive development and productive employment. In addition, policymakers should use legislation to create a robust social and economic welfare for all citizens, particularly for unemployed and poor households, to stabilise individuals' food security [70]. COVID-19 have a significant impact on the European agri-food sector as it has affected producer prices, which could disrupt global supply chains [71].

This study has some limitations in terms of the methodologies and variables chosen. The most important is the bias of the omitted variables, as the pillar variables only reflect the subjective decisions of the authors. The other is related to the dynamic characteristics and spatial differences of epidemic waves. Thus, the quantitative indicators measured before the transmission of the virus do not reflect the complete risks of an epidemic. They only concentrate on the expected exposures. However, the vulnerability also depends on the appropriate government responses and measures. The reader should bear in mind that the study is based on the current judgment of the authors. All information in this publication provided by the authors does not constitute any advice or opinion on specific economic policy issues and is therefore not responsible for its use.

Further research is needed to examine the structure of complex risk indicators related to the dilemma of selecting appropriate variables. Only a few quantitative analyses adequately addressed the relative importance of weights and the aggregate selection method for ranking. These indicators and methods are also essential for policymakers to continuously monitor and analyse progress towards sustainable development goals. Researchers may also consider using more comprehensive measures to assess risks in different regions and cities.

Author Contributions: Conceptualisation, S.K. and D.M.; methodology, S.K.; software, S.K.; validation, S.K.; formal analysis, S.K.; investigation, M.F.R.; resources, S.K.; data curation, S.K. and D.M.; writing—original draft preparation, D.M.; writing—review and editing, S.K., D.M. and M.F.R.; visualisation, S.K.; supervision, S.K.; funding acquisition, S.K. All authors have read and agreed to the published version of the manuscript.

Funding: This research was supported by ÚNKP-21-5-DE-3 New National Excellence Program of the Ministry for Innovation and Technology from the source of the National Research Development and Innovation Fund and was supported by the János Bolyai Research Scholarship of the Hungarian Academy of Sciences.

Institutional Review Board Statement: Not applicable.

Informed Consent Statement: Not applicable.

Data Availability Statement: Publicly available datasets were analyzed in this study. This data can be found here: https://solability.com/all-news/corona-risk-exposure-by-country (accessed on 20 July 2021); https://foodsecurityindex.eiu.com/Country (accessed on 11 May 2021); https: / / ourworldindata.org/ coronavirus (accessed on 26 July 2021).

Acknowledgments: This research was supported by the János Bolyai Research Scholarship of the Hungarian Academy of Science.

Conflicts of Interest: The authors declare no conflict of interest.

\section{References}

1. Valaskova, K.; Durana, P.; Adamko, P. Changes in Consumers' Purchase Patterns as a Consequence of the COVID-19 Pandemic. Mathematics 2021, 9, 1788. [CrossRef]

2. McKibbin, W.; Fernando, R. The Global Macroeconomic Impacts of COVID-19: Seven Scenarios. Asian Econ. Pap. 2021, 20 , 1-30. [CrossRef]

3. UNDG. Mainstreaming the 2030 Agenda for Sustainable Development-Reference Guide to UN Country Teams; United Nation Development Group: New York, NY, USA, 2017. 
4. Allen, C.; Metternicht, G.; Wiedmann, T. National pathways to the Sustainable Development Goals (SDGs): A comparative review of scenario modelling tools. Environ. Sci. Policy 2016, 66, 199-207. [CrossRef]

5. Clay, E. Chapter 2: Food Security: Concepts and Measurement. In World Food Summit; 1996; Available online: http:/ /www.fao. org/fileadmin/templates/faoitaly/documents/pdf/pdf_Food_Security_Cocept_Note.pdf (accessed on 26 July 2021).

6. Bhatt, A.; Arora, P.; Prajapati, S.K. Occurrence, fates and potential treatment approaches for removal of viruses from wastewater: A review with emphasis on SARS-CoV-2. J. Environ. Chem. Eng. 2020, 8, 104429. [CrossRef]

7. Arndt, C.; Lewis, J.D. The HIV/AIDS pandemic in South Africa: Sectoral impacts and unemployment. J. Int. Dev. 2001, 13, 427-449. [CrossRef]

8. Liu, J.; Hammitt, J.K.; Wang, J.; Tsou, M. Valuation of the risk of SARS in Taiwan. Health Econ. 2005, 14, 83-91. [CrossRef]

9. Noy, I.; Doan, N.; Ferrarini, B.; Park, D. Measuring the Economic Risk of COVID-19. Glob. Policy 2020, 11, 413-423. [CrossRef]

10. Epstein, J.M. Modelling to contain pandemics. Nature 2009, 460, 687. [CrossRef]

11. Horobet, A.; Simionescu, A.A.; Dumitrescu, D.G.; Belascu, L. Europe's war against COVID-19: A map of countries' disease vulnerability using mortality indicators. Int. J. Environ. Res. Public Health 2020, 17, 6565. [CrossRef]

12. Mathers, C.D.; Lopez, A.D.; Murray, C.J.L. The Burden of Disease and Mortality by Condition: Data, Methods, and Results for 2001. In Global Burden of Disease and Risk Factors; The International Bank for Reconstruction and Development/The World Bank: Washington, DC, USA, 2006; pp. 1-22, ISBN 0821362623.

13. Ahmad, A.; Chung, R.; Eckenwiler, L.; Ganguli-Mitra, A.; Hunt, M.; Richards, R.; Saghai, Y.; Schwartz, L.; Scully, J.L.; Wild, V. What does it mean to be made vulnerable in the era of COVID-19? Lancet 2020, 395, 1481-1482. [CrossRef]

14. Hallegatte, S.; Bangalore, M.; Vogt-Schilb, A. Assessing Socioeconomic Resilience to Floods in 90 Countries; World Bank: Washington, DC, USA, 2016; p. 7663.

15. Schoenbaum, S.C. Economic impact of influenza. Am. J. Med. 1987, 82, 26-30. [CrossRef]

16. Lee, J.-W.; McKibbin, W.J. Globalization and Disease: The Case of SARS. Asian Econ. Pap. 2004, 3, 113-131. [CrossRef]

17. McKibbin, W.J.; Sidorenko, A.A. Global Macroeconomic Consequences of Pandemic Influenza; Lowy Institute for International Policy: Sydney, Australia, 2006.

18. Gangemi, S.; Billeci, L.; Tonacci, A. Rich at risk: Socio-economic drivers of COVID-19 pandemic spread. Clin. Mol. Allergy 2020, 18, 1-3. [CrossRef]

19. $\mathrm{Wu}, \mathrm{T}$. The socioeconomic and environmental drivers of the COVID-19 pandemic: A review. Ambio 2021, 50, 822-833. [CrossRef] [PubMed]

20. Chou, J.; Kuo, N.-F.; Peng, S.-L. Potential Impacts of the SARS Outbreak on Taiwan's Economy. Asian Econ. Pap. 2004, 3, 84-99. [CrossRef]

21. Hai, W.; Zhao, Z.; Wang, J.; Hou, Z.-G. The Short-Term Impact of SARS on the Chinese Economy. Asian Econ. Pap. 2004, 3, 57-61. [CrossRef]

22. Siu, A.; Wong, Y.C.R. Economic Impact of SARS: The Case of Hong Kong. Asian Econ. Pap. 2004, 3, 62-83. [CrossRef]

23. SolAbility Corona: Economic Impact by Country. Available online: https://solability.com/all-news/corona-risk-exposure-bycountry (accessed on 20 July 2021).

24. EIU Global Food Security Index (GFSI). Available online: https:/ / foodsecurityindex.eiu.com/Country (accessed on 11 May 2021).

25. Ritchie, H.; Ortiz-Ospina, E.; Beltekian, D.; Mathieu, E.; Hasell, J.; Macdonald, B.; Giattino, C.; Appel, C.; Rodés-Guirao, L.; Roser, M. Coronavirus Pandemic (COVID-19). Available online: https: / / ourworldindata.org/ coronavirus (accessed on 26 July 2021).

26. Dutta, S.; Bilbao-Osorio, B. The Global Information Technology Report 2013: Living in a Hyperconnected World; World Economic Forum and INSEAD: Geneva, Switzerland, 2012.

27. World Economic Forum. The Global Competitiveness Report 2017-2018. Available online: https://www.weforum.org/reports/ the-global-competitiveness-report-2017-2018 (accessed on 4 February 2019).

28. Porter, M.; Schwab, K.; Sala-i-Martin, X.; López-Claros, A. (Eds.) The Global Competitiveness Report 2004-2005; WEF: Alexandria, VA, USA, 2004; ISBN 78-1403949134.

29. Thurstone, L.L. Multiple factor analysis. Psychol. Rev. 1931, 38, 406-427. [CrossRef]

30. Escofier, B.; Pages, J. Multiple factor analysis (AFMULT package). Comput. Stat. Data Anal. 1994, 18, 121-140. [CrossRef]

31. Choisis, J.P.; Thévenet, C.; Gibon, A. Analyzing farming systems diversity: A case study in south-western France. Span. J. Agric. Res. 2012, 10, 605-618. [CrossRef]

32. Yin, G.; Liu, L.; Yuan, C. Assessing environmental risks for high intensity agriculture using the material flow analysis method -A case study of the Dongting Lake basin in South Central China. Environ. Monit. Assess. 2015, 187, 1-17. [CrossRef]

33. Máté, D.; Rabbi, M.F.; Novotny, A.; Kovács, S. Grand Challenges in Central Europe: The Relationship of Food Security, Climate Change, and Energy Use. Energies 2020, 13, 5422. [CrossRef]

34. Visbal-Cadavid, D.; Martínez-Gómez, M.; Escorcia-Caballero, R. Exploring University Performance through Multiple Factor Analysis: A Case Study. Sustainability 2020, 12, 924. [CrossRef]

35. Pagés, J.; Husson, F. Multiple factor analysis with confidence ellipses: A methodology to study the relationships between sensory and instrumental data. J. Chemom. 2005, 19, 138-144. [CrossRef]

36. Koren, D.; Lőrincz, L.; Kovács, S.; Kun-Farkas, G.; Vecseriné Hegyes, B.; Sipos, L. Comparison of supervised learning statistical methods for classifying commercial beers and identifying patterns. J. Chemom. 2020, 34, 1-9. [CrossRef] 
37. Bécue-Bertaut, M.; Kern, J.; Hernández-Maldonado, M.-L.; Juresa, V.; Vuletic, S. Health-risk behaviour in Croatia. Public Health 2008, 122, 140-150. [CrossRef]

38. Bécue-Bertaut, M.; Pagès, J. Multiple factor analysis and clustering of a mixture of quantitative, categorical and frequency data. Comput. Stat. Data Anal. 2008, 52, 3255-3268. [CrossRef]

39. Zárraga, A.; Goitisolo, B. Simultaneous analysis and multiple factor analysis for contingency tables: Two methods for the joint study of contingency tables. Comput. Stat. Data Anal. 2009, 53, 3171-3182. [CrossRef]

40. Abdi, H.; Williams, L.J.; Valentin, D. Multiple factor analysis: Principal component analysis for multitable and multiblock data sets. Wiley Interdiscip. Rev. Comput. Stat. 2013, 5, 149-179. [CrossRef]

41. Pagès, J. Multiple factor analysis and procrustes analysis. In Multiple Factor Analysis by Example Using R; Chapman and Hall: London, UK, 2014; ISBN 9781482205473.

42. Husson, F.; Josse, J.; Lê, S. FactoMineR: An R Package for Multivariate Analysis. J. Stat. Softw. 2008, 25, 1-18. [CrossRef]

43. Stone, M. An Asymptotic Equivalence of Choice of Model by Cross-Validation and Akaike's Criterion. J. R. Stat. Soc. Ser. B 1977, 39, 44-47. [CrossRef]

44. Kohavi, R. A Study of Cross-Validation and Bootstrap for Accuracy Estimation and Model Selection. In Proceedings of the International Joint Conference on Artificial Intelligence, Montreal, QC, Canada, 20-25 August 1995; Volume 14, pp. 1137-1143. [CrossRef]

45. Allen, D.M. The Relationship Between Variable Selection and Data Augmentation and a Method for Prediction. Technometrics 1974, 16, 125-127. [CrossRef]

46. Wilcoxon, F. Individual Comparisons by Ranking Methods. Biom. Bull. 1945, 1, 80-83. [CrossRef]

47. WHO. Information Note on COVID-19 and NCDs; WHO: Geneva, Switzerland, 2021.

48. Kashnitsky, I.; Aburto, J.M. COVID-19 in unequally ageing European regions. World Dev. 2020, 136, 105170. [CrossRef] [PubMed]

49. Azarpazhooh, M.R.; Morovatdar, N.; Avan, A.; Phan, T.G.; Divani, A.A.; Yassi, N.; Stranges, S.; Silver, B.; Biller, J.; Tokazebani Belasi, M.; et al COVID-19 Pandemic and Burden of Non-Communicable Diseases: An Ecological Study on Data of 185 Countries. J. Stroke Cerebrovasc. Dis. 2020, 29, 105089. [CrossRef] [PubMed]

50. Schröder, M. Jobless now, sick later? Investigating the long-term consequences of involuntary job loss on health. Adv. Life Course Res. 2013, 18, 5-15. [CrossRef]

51. Javed, B.; Sarwer, A.; Soto, E.B.; Mashwani, Z.-R. Impact of SARS-CoV-2 (Coronavirus) Pandemic on Public Mental Health. Front. Public Health 2020, 8, 292. [CrossRef]

52. Ji, Y.; Ma, Z.; Peppelenbosch, M.P.; Pan, Q. Potential association between COVID-19 mortality and health-care resource availability. Lancet Glob. Health 2020, 8, e480. [CrossRef]

53. Codagnone, C.; Bogliacino, F.; Gómez, C.; Charris, R.; Montealegre, F.; Liva, G.; Lupiáñez-Villanueva, F.; Folkvord, F.; Veltri, G.A. Assessing concerns for the economic consequence of the COVID-19 response and mental health problems associated with economic vulnerability and negative economic shock in Italy, Spain, and the United Kingdom. PLoS ONE 2020, 15, e0240876. [CrossRef]

54. Pieh, C.; Budimir, S.; Probst, T. The effect of age, gender, income, work, and physical activity on mental health during coronavirus disease (COVID-19) lockdown in Austria. J. Psychosom. Res. 2020, 136, 110186. [CrossRef]

55. Grané, A.; Albarrán, I.; Merchán, D.E. Impact of Pandemic on European Well-Being: Visualising Scenarios from the SHARE Database. Int. J. Environ. Res. Public Health 2021, 18, 4620. [CrossRef] [PubMed]

56. Victor, V.; Karakunnel, J.J.; Loganathan, S.; Meyer, D.F. From a Recession to the COVID-19 Pandemic: Inflation-Unemployment Comparison between the UK and India. Economies 2021, 9, 73. [CrossRef]

57. Sharma, A.; Borah, S.B.; Moses, A.C. Responses to COVID-19: The role of governance, healthcare infrastructure, and learning from past pandemics. J. Bus. Res. 2021, 122, 597-607. [CrossRef]

58. Muangmee, C.; Kot, S.; Meekaewkunchorn, N.; Kassakorn, N.; Khalid, B. Factors Determining the Behavioral Intention of Using Food Delivery Apps during COVID-19 Pandemics. J. Theor. Appl. Electron. Commer. Res. 2021, 16, 1297-1310. [CrossRef]

59. Wong, S.H.; Lui, R.N.S.; Sung, J.J.Y. COVID-19 and the digestive system. J. Gastroenterol. Hepatol. 2020, 35, 744-748. [CrossRef]

60. Lakner, C.; Mahler, D.G.; Negre, M.; Prydz, E.B. How Much Does Reducing Inequality Matter for Global Poverty? World Bank: Washington, DC, USA, 2019.

61. United Nations. The Secretary-General's UN COVID-19 Response and Recovery Fund; UN: New York, NY, USA, 2020.

62. Popp, J.; Lakner, Z.; Harangi-Rákos, M.; Fári, M. The effect of bioenergy expansion: Food, energy, and environment. Renew. Sustain. Energy Rev. 2014, 32, 559-578. [CrossRef]

63. Blesh, J.; Hoey, L.; Jones, A.D.; Friedmann, H.; Perfecto, I. Development pathways toward "zero hunger". World Dev. 2019, 118, 1-14. [CrossRef]

64. Zhang, X.; Vesselinov, V.V. Integrated modeling approach for optimal management of water, energy and food security nexus. Adv. Water Resour. 2017, 101, 1-10. [CrossRef]

65. Bretschger, L.; Smulders, S. Technologies, preferences, and policies for a sustainable use of natural resources. Resour. Energy Econ. 2011, 33, 881-892. [CrossRef]

66. Calvin, K.; Bond-Lamberty, B.; Clarke, L.; Edmonds, J.; Eom, J.; Hartin, C.; Kim, S.; Kyle, P.; Link, R.; Moss, R.; et al. The SSP4: A world of deepening inequality. Glob. Environ. Chang. 2017, 42, 284-296. [CrossRef] 
67. Meurens, F.; Dunoyer, C.; Fourichon, C.; Gerdts, V.; Haddad, N.; Kortekaas, J.; Lewandowska, M.; Monchatre-Leroy, E.; Summerfield, A.; Wichgers Schreur, P.J.; et al. Animal board invited review: Risks of zoonotic disease emergence at the interface of wildlife and livestock systems. Animal 2021, 15, 100241. [CrossRef] [PubMed]

68. Merino-Saum, A.; Baldi, M.G.; Gunderson, I.; Oberle, B. Articulating natural resources and sustainable development goals through green economy indicators: A systematic analysis. Resour. Conserv. Recycl. 2018, 139, 90-103. [CrossRef]

69. Aceleanu, M.I.; Serban, A.C.; Tîrcă, D.M.; Badea, L. The rural sustainable development through renewable energy. The case of Romania. Technol. Econ. Dev. Econ. 2018, 24, 1408-1434. [CrossRef]

70. United Nations Environment Programme. A UN Framework for the Immediate Socio-Economic Response to COVID-19; UN: New York, NY, USA, 2020.

71. Hamulczuk, M.; Skrzypczyk, M. COVID-19, spatial market integration and producer prices: A case study of EU agri-food markets. Stud. Agric. Econ. 2021, 123, 53-61. [CrossRef] 